\title{
Comparative Evaluation of Organic manure from Some Invasive Plants, Poultry Manure and NPK on the Growth of Corchorus olitorius L
}

\author{
"SANYAOLU, VT; ADEPOJU, IH \\ Environmental Biology Unit, Department of Biological Science, School of Pure and Applied Sciences, Lagos State Polytechnic, Ikorodu, \\ Lagos, Nigeria, \\ "Corresponding Author Email: vaksanyaolu@yahoo.com; Tel: +234-808-741-2679
}

\begin{abstract}
This study compares the effect of organic manure prepared using green leaf of five Invasive plants with poultry manure and NPK on the growth of Corchorous olitorius. The plants employed were Tithonia diversifolia (T1), Eichhornia crassipes (T2), Chromolaena odorata (T3), Euphobia graminea (T4), Alternanthera brasiliana (T5). The experiment was conducted by applying $3 \mathrm{~g} / \mathrm{kg}$ each of T1, T2 T3, T4, T5, dried poultry manure (T6) and $2 \mathrm{~g} / \mathrm{kg}$ of NPK (15:15:15) (T7) to $5 \mathrm{~kg}$ of soil. Seeds of $C$. olitorius were applied and seedlings thinned to three per pot. Plant height, number of leaves, leaf area, stem girth, days to flowering and fresh biomass were measured between three to nine weeks after planting. Highest mean parameters occurred in T6 in the first six weeks for plant height and leaf area, first three weeks for number of leaves and the sixth week for stem girth. At harvest, highest plant height, leaf area,

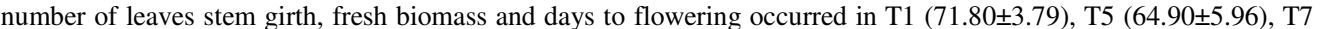
$(21.48 \pm 2.41) \mathrm{T} 5(56.38 \pm 4.59) \mathrm{T} 5(1.60 \pm 0.04)$ and $\mathrm{T} 4(69.25 \pm 0.48)$ respectively, whereas, lowest mean parameters occurred in the control (T8). Among treated soils, $C$. odorata and E. graminea recorded least mean values from week five. Data analysis by one-way ANOVA and Duncan's multiple range test (DMRT) revealed significant differences $(\mathrm{P} \geq 0.05)$ in all parameters except days to first flowering. This is probably a first report on the use of Alternanthera brasiliana and Euphorbia graminea as green manure.
\end{abstract}

\section{DOI: https://dx.doi.org/10.4314/jasem.v22i8.7}

Copyright: Copyright (C) 2018 Sanyaolu and Adepoju. This is an open access article distributed under the Creative Commons Attribution License (CCL), which permits unrestricted use, distribution, and reproduction in any medium, provided the original work is properly cited.

Dates: Received: 07July 2018; Revised: 19 August: 2018; Accepted: 26August 2018

Keywords: Invasive plants, Green leaf manure, Corchorous olitorius, NPK

The growing need to achieve food security for a rapidly expanding population has led to exploitation of cropland resources in tropical Africa (Hossner and Anthony, 1999; Gibbs et al., 2010). Consequently, this has caused degradation of available soil resources in the region (Gibbs et al., 2010), with the attendant ecological problems of soil erosion and nutrient leaching, thus, posing a serious threat to sustainable food production in this highly populated region (Tully et al., 2015). Use of inorganic fertilizer has been the quickest and easiest way of increasing yield per unit area (Law-Ogbomo and Remison 2007). However, the problem with inorganic fertilizer application is that it leads to pollution of ground water and long term deterioration of soil physical properties especially the soil structure, owing to the depletion of organic matter (Gordon et al., 1993). Moreover, inorganic fertilizer is no longer within the reach of resource-poor farmers in the region due to its high cost (Rahman, 2004).

For centuries, the use of organic fertilizers has been synonymous with successful and stable agriculture (Steffen, 1979). Efforts at remediating soil fertility have basically been achieved using traditional organic materials, which have been recognized to have significant effect on sustainability of soil nutrient and yield of agricultural product (Oyetunji et al., 2003). Many crops respond well to the application of organic fertilizer obtained from composted organic materials (Ibeawuchi et al., 2006). The use of organic materials can significantly improve the physical, chemical and microbial characteristics of cultivated soil and increase crop production (Steffen, 1979; Darmody et al., 1983; Pera et al., 1983). Furthermore, in recent years, an increasing number of health-conscious consumers prefer foods grown on soils to which only natural organic materials have been added. Global sales of organic food products have increased at a rate of more than $\$ 5$ billion annually (Willer et al., 2008). However, traditional organic materials such as animal manure are not usually available in sufficient quantities, may have low nutrients and their processing and application are labour intensive (Palm et al., 1997), hence, the need for other alternatives.

The use of decayed tissues of unwanted plants to provide nutrients for crops is a crude but effective way of exploiting weeds and is a simpler technique than

* Corresponding Author Email: vaksanyaolu@yahoo.com; Tel: +234-808-741-2679 
any of the other alternatives (Nuka and Dubey, 2011). The Nigerian ecosystems have been invaded by a large number of invasive alien plant species. Invasive alien species (IAS) are a major global challenge requiring urgent action (Xu et al., 2012). They are considered one of the key pressures on world's biodiversity, altering ecosystem services and processes, reducing native species abundance and richness, and decreasing genetic diversity of ecosystems (Hejda et al., 2009; Rands et al., 2010; Vila et al., 2011). Most exotics, once established are permanent and eradication is possible in few instances, but only at great expense and effort, since many of the control methods for IAS are expensive, slow and in some cases ineffective (Coblentz, 2002). In view of the foregoing, there is the need for alternative means of dealing with these species, which may be through their utilization. This involves the use of their huge biomass for human welfare instead of destroying them (Chandrasekaran and Swamy 2009). These plants however, apart from their high biomass production, can decompose quickly and therefore could be utilized as green leaf manure to improve soil fertility. This study was conducted to assess the effect of green leaf manure prepared from Tithonia diversifolia, Chromoleana odorata, Eichhonia crassipes, Alternanthera brasiliana, and Euphorbia graminea compared with that of poultry manure and inorganic fertilizer (NPK) on selected growth parameters of Corchorous olitorius.

\section{MATERIALS AND METHODS}

This study was conducted as a pot experiment in the Green House belonging to Environmental Biology Unit, Lagos State Polytechnic, Ikorodu, Lagos state, Nigeria, located N 0640'16.6” and E 003³1 '55.3”.

Collection of the test materials: Invasive plant species were collected from various locations where they grow as weeds within and outside Lagos state, Nigeria. Poultry manure, NPK (15:15:15) fertilizer and seed of C. olitorius were obtained from the Department of Agriculture, Lagos State Polytechnic, Ikorodu.

Soil preparation and application of Treatments: A well-drained soil was collected beside the Biological garden located in Lagos state polytechnic Ikorodu, Lagos. The collected soil was mixed thoroughly to obtain homogeneity. Then, $5 \mathrm{~kg}$ of the soil was measured into a $10 \mathrm{~cm}^{2}$ perforated plastic containers prior to application of the test materials. Fresh leaves of five common IAS [Tithonia diversifolia (Mexican sunflower) (T1), Eichhornia crassipes (Water hyacinth) (T2), Chromolaena odorata (Siam weed) (T3), Euphobia graminea (Grass leaf spurge) (T4) and Alternanthera brasiliana (Brazilian joy weed) (T5)] were first separated from the stem. Exactly $3 \mathrm{~g} / \mathrm{kg}$ of each was applied to already prepared soil. Dried poultry manure was also applied rate of $3 \mathrm{~g} / \mathrm{kg}$. These were left for four weeks to decompose. Water was sprinkled regularly to hasten the decomposition process. Decomposed materials were mixed with the top soil at the end of 4 weeks .NPK (15: 15:15) fertilizer formulated in granules was applied at the rate of $2 \mathrm{~g} / \mathrm{kg}$ per pot (Dania et al., 2014) and left for 48 hours before seed application. The control soil (T8) received no treatment.

Seed treatment and application: Treated seeds were applied to the soil by simple broadcasting method. Germinated seeds were thinned to three plants per pot nine day after planting.

Experimental design: The experiment which included seven treatments and a control was set up in 4 replicates using Complete Randomized Design (CRD).

Measurement of growth parameters in C. olitorius: Selected growth parameters of $C$. olitorius were measured to compare the effects of different green leaf manure prepared using invasive alien plant species, poultry manure and NPK fertilizer. Plant height, number of leaves per plant (LN) and leaf area (LA) commenced three weeks after planting (denoted week one of measurement in this study), stem girth commenced in the seventh week, days to first flowering were documented as observed in each plant. The experiment was concluded in the ninth week by measuring the biomass (fresh weight). All three plants per pot were measured and values obtained for each parameter were mean of three plants. Plant height was measured by placing a one-meter ruler from the base of each C. olitorius plant to the tip of the main shoot. A $30 \mathrm{~cm}$ ruler was used to measure the LA (lengthx breath). The number of leaves was by direct count. The girth was measured using a rope and then stretched over a $30 \mathrm{~cm}$ ruler. Weight of fresh biomass was obtained using the analytical balance (Metler electronic balance M200).

Statistical analysis of the data: Results obtained were subjected to analysis of variance (ANOVA) in complete Randomization Design (CRD) using the Statistical Package for the Social Sciences (SPSS) 15.0 software. Mean separation was carried out at 5\% level of significance using the Duncan's multiple range test (DMRT). Each parameter was mean of three plants in four replicates. 


\section{RESULTS AND DISCUSSION}

Effect of treatments on growth parameters of $C$. olitorius at week one: Table 1 shows the result of growth parameters of $C$. olitorius in the first week of measurement (that is, 3rd week after planting). Highest mean plant height $(10.43 \mathrm{~cm})$, leaf area (LA) $\left(9.95 \mathrm{~cm}^{2}\right)$ and numbers of leaves (LN) (5.08) occurred in T6 (Chicken manure). Tithonia diversifolia (T1) followed with values $10.18 \mathrm{~cm}, 6.83 \mathrm{~cm}^{2}, 4.58$ respectively. Lowest mean plant height $(8.03 \mathrm{~cm})$ and number of leaves $(3.33 \mathrm{~cm}$ ) occurred in T4 (Euphorbia graminea), while least mean LA $\left(2.93 \mathrm{~cm}^{2}\right)$ occurred in T5 (Alternanthera brasiliana) (Table 1). There was no significant difference $(\mathrm{P} \leq 0.05)$ in mean plant height between all the treatments except $\mathrm{T} 4$ which was significantly lower $(\mathrm{P} \leq 0.05)$ than $\mathrm{T} 6$ and $\mathrm{T} 1$. In mean LA, T6 was significantly higher $(\mathrm{P} \geq 0.05)$ than all other treatments, whereas, in mean number of leaves, there were no significant differences $(\mathrm{P} \leq 0.05)$ between all other treatments except that T4 and T8 (Control) were significantly lower $(\mathrm{P} \leq 0.05)$ than T6(Table 1$)$.

Effect of treatments on growth parameters of $C$. olitorius at week two: In the second week, result followed a similar pattern to that observed in the $1^{\text {st }}$ week. T6 (Chicken manure) had the highest mean value in all three parameters and was also followed by T1 (Tithonia diversifolia) (Table 1). T6 was significantly higher $(\mathrm{P} \geq 0.05)$ than all other treatments in mean plant height and mean LA but only significantly higher $(\mathrm{P} \geq 0.05)$ than $\mathrm{T} 4$ (Euphorbia graminea), T5 (Alternanthera brasiliana) and T8 (Control) in mean LN (Table 1). Least mean values were obtained in T5 for plant height $(9.43 \mathrm{~cm})$ and LA $\left(3.98 \mathrm{~cm}^{2}\right)$ whereas, least mean LN was observed in T4 (Table 1). NPK was third place in most parameters in week one and fourth in week two.

Effect of treatments on growth parameters of $C$. olitorius at week three: In the third week of measurement, T6 and T1 again recorded the first and second highest mean values respectively in plant height, LN and LA parameters (Table 2). T6 was significantly higher $(\mathrm{P} \geq 0.05)$ than all other treatments except T1 and T7 in mean plant height. In mean LA, T6, was significantly higher $(\mathrm{P} \geq 0.05)$ than all other treatments (Table 2) whereas, it was significantly higher $(\mathrm{P} \geq 0.05)$ than $\mathrm{T} 4, \mathrm{~T} 5, \mathrm{~T} 7$ and $\mathrm{T} 8$ in mean LN. T5 recorded the least mean plant height and was significantly lower $(\mathrm{P} \leq 0.05)$ than $\mathrm{T} 1$ and $\mathrm{T} 6$. Least mean LA and LN were recorded in $\mathrm{T} 4$ and in both cases were significantly lower $(\mathrm{P} \leq 0.05)$ than $\mathrm{T} 6$ and T1 (Table 2).

Table 1. Mean growth parameters of C. olitorius in first and second weeks of measurement

\begin{tabular}{|c|c|c|c|c|c|c|}
\hline \multirow[b]{2}{*}{$\mathrm{T}$} & \multicolumn{3}{|c|}{ Week one } & \multicolumn{3}{|c|}{ Week two } \\
\hline & $\begin{array}{c}\text { Plant } \\
\text { height }(\mathrm{cm})\end{array}$ & $\mathrm{LA}\left(\mathrm{cm}^{2}\right)$ & $\begin{array}{l}\text { No. of } \\
\text { leaves }\end{array}$ & $\begin{array}{c}\text { Plant } \\
\text { Height }(\mathrm{cm})\end{array}$ & $\begin{array}{c}\text { Leaf } \\
\operatorname{area}\left(\mathrm{cm}^{2}\right)\end{array}$ & $\begin{array}{l}\text { No. of } \\
\text { Leaves }\end{array}$ \\
\hline $\mathrm{T} 1$ & $10.18 \pm 0.52^{\mathrm{b}}$ & $6.83 \pm 1.22^{\mathrm{c}}$ & $4.58 \pm 0.36^{\mathrm{ab}}$ & $12.70 \pm 0.14^{b}$ & $8.95 \pm 1.49^{b}$ & $5.50 \pm 0.31^{\mathrm{bc}}$ \\
\hline $\mathrm{T} 2$ & $8.38 \pm 0.55^{\mathrm{ab}}$ & $4.88 \pm 0.92^{\mathrm{abc}}$ & $4.03 \pm 0.47^{\mathrm{ab}}$ & $10.88 \pm 0.74^{\mathrm{ab}}$ & $6.65 \pm 1.22^{\mathrm{ab}}$ & $5.33 \pm 0.14^{\mathrm{bc}}$ \\
\hline $\mathrm{T} 3$ & $9.20 \pm 0.65^{\mathrm{ab}}$ & $3.25 \pm 0.29^{\mathrm{ab}}$ & $3.85 \pm 0.30^{\mathrm{ab}}$ & $10.50 \pm 0.41^{\mathrm{a}}$ & $4.63 \pm 0.35^{\mathrm{a}}$ & $4.93 \pm 0.37^{\mathrm{abc}}$ \\
\hline $\mathrm{T} 4$ & $8.03 \pm 0.42^{\mathrm{a}}$ & $3.58 \pm 0.63^{\mathrm{ab}}$ & $3.33 \pm 0.37^{\mathrm{a}}$ & $10.25 \pm 0.73^{\mathrm{ab}}$ & $4.98 \pm 0.83^{\mathrm{ab}}$ & $3.90 \pm 0.46^{\mathrm{a}}$ \\
\hline $\mathrm{T} 5$ & $8.43 \pm 0.55^{\mathrm{ab}}$ & $2.93 \pm 0.24^{\mathrm{a}}$ & $3.90 \pm 0.24^{\mathrm{ab}}$ & $9.43 \pm 0.49^{\mathrm{a}}$ & $3.98 \pm 0.36^{\mathrm{a}}$ & $4.83 \pm 0.28^{\mathrm{ab}}$ \\
\hline T6 & $10.43 \pm 1.03^{\mathrm{b}}$ & $9.95 \pm 1.31^{\mathrm{d}}$ & $5.08 \pm 0.61^{\mathrm{b}}$ & $13.48 \pm 0.97^{c}$ & $14.53 \pm 2.54^{\mathrm{c}}$ & $6.05 \pm 0.63^{\mathrm{c}}$ \\
\hline $\mathrm{T} 7$ & $9.20 \pm 0.47^{\mathrm{ab}}$ & $6.15 \pm 1.16^{\mathrm{bc}}$ & $4.33 \pm 0.37^{\mathrm{ab}}$ & $12.10 \pm 0.30^{\mathrm{ab}}$ & $7.78 \pm 1.32^{\mathrm{ab}}$ & $5.08 \pm 0.14^{\mathrm{bc}}$ \\
\hline Т 8 & $8.63 \pm 0.62^{\mathrm{ab}}$ & $4.28 \pm 0.81^{\mathrm{abc}}$ & $3.60 \pm 0.21^{\mathrm{a}}$ & $10.03 \pm 0.94^{\mathrm{ab}}$ & $5.58 \pm 1.04^{\mathrm{ab}}$ & $4.53 \pm 0.18^{\mathrm{ab}}$ \\
\hline
\end{tabular}

Mean values of the same parameter along the same column having the same superscript are not significantly different (DMRT.P=0.05) $\mathrm{T} 1=$ Tithonia diversifolia $; \mathrm{T} 2=$ Eichhornia crassipes: $\mathrm{T} 3=$ Chromolaena odorata $: \mathrm{T} 4=$ Euphorbia graminea $; \mathrm{T} 5=$ Alternanthera brasiliana $; \mathrm{T} 6=$ Chicken manure; $\mathrm{T} 7=$ N.P.K (15:15:15): $\mathrm{T} 8=$ Control (no treatment); $\mathrm{T}=$ Treatment

Table 2. Mean growth parameters for C.olitorius in third and fourth weeks of measurement

\begin{tabular}{lccl|lrr}
\hline & $\begin{array}{c}\text { Week three } \\
\text { Plant }\end{array}$ & $\begin{array}{c}\text { Leaf } \\
\text { area }\left(\mathrm{cm}^{2}\right)\end{array}$ & $\begin{array}{l}\text { No. } \\
\text { of leaves }\end{array}$ & $\begin{array}{c}\text { Plant } \\
\text { Height }(\mathrm{cm})\end{array}$ & $\begin{array}{c}\text { Week four } \\
\text { Leaf } \\
\text { area }\left(\mathrm{cm}^{2}\right)\end{array}$ & $\begin{array}{c}\text { No. } \\
\text { of leaves }\end{array}$ \\
\hline T 1 & $15.70 \pm 0.58^{\text {cd }}$ & $19.33 \pm 2.14^{\mathrm{b}}$ & $7.18 \pm 0.73^{\mathrm{bc}}$ & $23.85 \pm 1.84^{\mathrm{ab}}$ & $22.83 \pm 2.03^{\mathrm{b}}$ & $6.50 \pm 0.69^{\mathrm{a}}$ \\
T 2 & $13.50 \pm 1.16^{\mathrm{bc}}$ & $12.10 \pm 2.32^{\mathrm{ab}}$ & $6.90 \pm 0.81^{\mathrm{abc}}$ & $23.58 \pm 1.50^{\mathrm{ab}}$ & $22.18 \pm 2.26^{\mathrm{b}}$ & $6.35 \pm 0.30^{\mathrm{a}}$ \\
T 3 & $11.88 \pm 0.61^{\mathrm{ab}}$ & $10.08 \pm 1.26^{\mathrm{a}}$ & $6.93 \pm 0.30^{\mathrm{abc}}$ & $20.45 \pm 0.93^{\mathrm{a}}$ & $17.68 \pm 0.72^{\mathrm{ab}}$ & $6.15 \pm 0.43^{\mathrm{a}}$ \\
T 4 & $11.50 \pm 0.41^{\mathrm{ab}}$ & $9.40 \pm 0.89^{\mathrm{a}}$ & $5.35 \pm 0.24^{\mathrm{a}}$ & $20.40 \pm 0.70^{\mathrm{a}}$ & $17.63 \pm 2.08^{\mathrm{ab}}$ & $5.25 \pm 0.44^{\mathrm{a}}$ \\
T 5 & $10.75 \pm 0.55^{\mathrm{a}}$ & $9.95 \pm 0.16^{\mathrm{a}}$ & $5.65 \pm 0.30^{\mathrm{ab}}$ & $21.73 \pm 1.27^{\mathrm{ab}}$ & $15.13 \pm 2.21^{\mathrm{a}}$ & $5.78 \pm 0.35^{\mathrm{a}}$ \\
T 6 & $16.90 \pm 1.22^{\mathrm{d}}$ & $27.58 \pm 5.03^{\mathrm{c}}$ & $7.83 \pm 0.28^{\mathrm{c}}$ & $26.03 \pm 2.22^{\mathrm{c}}$ & $29.58 \pm 0.63^{\mathrm{c}}$ & $8.00 \pm 0.68^{\mathrm{b}}$ \\
T 7 & $14.75 \pm 0.53^{\mathrm{cd}}$ & $18.53 \pm 2.41^{\mathrm{b}}$ & $5.83 \pm 0.21^{\mathrm{ab}}$ & $21.65 \pm 2.33^{\mathrm{ab}}$ & $20.05 \pm 2.42^{\mathrm{ab}}$ & $6.65 \pm 0.30^{\mathrm{ab}}$ \\
T 8 & $11.55 \pm 0.97^{\mathrm{ab}}$ & $10.20 \pm 1.92^{\mathrm{a}}$ & $6.25 \pm 0.59^{\mathrm{ab}}$ & $19.10 \pm 1.40^{\mathrm{a}}$ & $14.10 \pm 1.68^{\mathrm{a}}$ & $5.83 \pm 0.34^{\mathrm{a}}$ \\
\hline
\end{tabular}

Mean values of the same parameter along the same column having the same superscript are not significantly different (DMRT.P=0.05);

$\mathrm{T} 1$ = Tithonia diversifolia $; \mathrm{T} 2=$ Eichhornia crassipes $; \mathrm{T} 3=$ Chromolaena odorata $; \mathrm{T} 4=$ Euphorbia graminea $;$

T5 = Alternanthera brasiliana $; \mathrm{T} 6=$ Chicken manure; T7 = N.P.K (15:15:15); T8 = Control (no treatment); T= treatments 
Effect of treatments on growth parameters of $C$. olitorius at week four: At week four, T6 (Chicken manure) was significantly higher $(\mathrm{P} \geq 0.05)$ in mean plant height, mean LA and LN than all other treatments except T7 (NPK) in only mean number of leaves. T1 (Tithonia diversifolia), T2 (Eichhornia crassipes $)$ were significantly higher $(\mathrm{P} \geq 0.05)$ than $\mathrm{T} 4$ and T8 (Control) in mean plant height (Table 2). T8 had the least mean plant height and LA, whereas, T4 (Euphorbia graminea) had the least mean LN though not significantly different $(\mathrm{P} \leq 0.05)$ from all other treatments except T6 (Table 2).

Effect of treatments on growth parameters of $C$. olitorius at week five: In the fifth week, highest mean plant height, LA and stem girth occurred in T6 (Chicken dung) with values $32.10 \mathrm{~cm}, 43.33 \mathrm{~cm}^{2}$ and $1.03 \mathrm{~cm}$ respectively (Table 3$)$. T7 (NPK) had the highest mean LN $(9.25 \mathrm{~cm})$. In mean LA, T6 was significantly higher $(\mathrm{P} \geq 0.05)$ than all other treatments, whereas, in mean LN, T7 was significantly higher $(\mathrm{P} \leq 0.05)$ than all treatments except T6 (Chicken manure), T1 (Tithonia diversifolia) and T5 (Alternanthera brasiliana). Furthermore, in mean stem girth, no significant difference $(\mathrm{P} \leq 0.05)$ occurred between T1, T2 and T5 (Table 3). T8 had the lowest mean values in all parameters with lowest mean stem girth $(0.55 \mathrm{~cm})$ occurring in both $\mathrm{T} 8$ and $\mathrm{T} 3$ (Chromolaena odorata) (Table 3).

Table 3: Mean growth parameters for C.olitorius in fifth and sixth weeks of measurement

\begin{tabular}{|c|c|c|c|c|c|c|c|}
\hline $\begin{array}{l}\text { Plant } \\
\text { Height (cm) }\end{array}$ & $\begin{array}{l}\text { WEEK FIV E } \\
\text { Leaf area }\left(\mathrm{cm}^{2}\right)\end{array}$ & $\begin{array}{l}\text { No. of } \\
\text { leaves }\end{array}$ & Girth $(\mathrm{cm})$ & $\begin{array}{l}\text { Plant Height } \\
(\mathrm{cm})\end{array}$ & $\begin{array}{l}\text { Leaf } \\
\text { area }\left(\mathrm{cm}^{2}\right)\end{array}$ & No. of leaves & Girth $(\mathrm{cm})$ \\
\hline $30.95 \pm 2.09^{a b}$ & $33.43 \pm 2.28^{c}$ & $8.23 \pm 1.37^{\mathrm{ke}}$ & $0.83 \pm 0.13^{2}$ & $56.08 \pm 2.68^{b}$ & $50.58 \pm 3.74^{4}$ & $13.93 \pm 2.26^{b}$ & $1.30 \pm 0.10^{\circ}$ \\
\hline $30.43 \pm 2.05^{a b}$ & $31.05 \pm 2.83^{x}$ & $6.93 \pm 0.47^{a}$ & $0.80 \pm 0.16^{\prime}$ & $55.43 \pm 2.62^{b}$ & $51.58 \pm 4.03 \Rightarrow$ & $11.98 \pm 0.62^{=}$ & $1.30 \pm 0.09$ \\
\hline $26.55 \pm 1.33^{\mathrm{ab}}$ & $23.78 \pm 1.32=$ & $6.90 \pm 0.24=$ & $0.55 \pm 0.05=$ & $49.58 \pm 2.17^{\mathrm{b}}$ & $45.43 \pm 3.61^{\mathrm{t}}$ & $12.68 \pm 0.74=$ & $1.20 \pm 0.06^{6}$ \\
\hline $\begin{array}{l}26.55 \pm 0.62^{\mathrm{ab}} \\
28.65 \pm 0.91^{\mathrm{a}}\end{array}$ & $\begin{array}{l}24.30 \pm 3.08 \mathrm{ab} \\
26.60 \pm 1.50^{\mathrm{b} c}\end{array}$ & $\begin{array}{l}6.60 \pm 0.40^{\mathrm{h}} \\
8.00 \pm 0.60^{\mathrm{h} e}\end{array}$ & $\begin{array}{l}0.58 \pm 0.05^{2} \\
0.75 \pm 0.09^{2}\end{array}$ & $\begin{array}{l}46.75 \pm 0.88^{\mathrm{b}} \\
53.08 \pm 2.88^{b}\end{array}$ & $\begin{array}{l}43.38 \pm 3.90^{\mathrm{h}} \\
60.50 \pm 4.31^{\mathrm{c}}\end{array}$ & $\begin{array}{l}11.68 \pm 1.52^{\mathrm{b}} \\
13.68 \pm 0.82^{\mathrm{b}}\end{array}$ & $\begin{array}{l}1.23=0.05^{b} \\
1.38=0.05^{b}\end{array}$ \\
\hline $32.10 \pm 3.32^{z}$ & $43.33 \pm 5.77^{d}$ & $9.00 \pm 0.36^{e}$ & $1.03 \pm 0.14^{\prime}$ & $56.63 \pm 5.05^{b}$ & $54.35 \pm 8.29^{\prime \prime}$ & $14.43 \pm 1.91^{b}$ & $1.40 \pm 0.09$ \\
\hline $26.38 \pm 2.39^{\circ b}$ & $28.78 \pm 0.75^{x}$ & $9.25 \pm 0.48^{e}$ & $0.68=0.06$ & $50.55 \pm 2.75^{b}$ & $47.33 \pm 2.04^{*}$ & $13.33 \pm 1.08^{=}$ & $1.28=0.05^{b}$ \\
\hline $25.35 \pm 1.87^{2}$ & $18.15 \pm 1.61^{2}$ & $6.15 \pm 0.09^{2}$ & $0.55 \pm 0.06^{2}$ & $40.78 \pm 3.86^{2}$ & $29.38 \pm 2.87^{2}$ & $9.40 \pm 0.40^{2}$ & $0.98 \pm 0.03^{2}$ \\
\hline
\end{tabular}

Mean values of the same parameter along the same column having the same superscript are not significantly different (DMRT.P=0.05); $\mathrm{T} 1$ =Tithonia diversifolia; $\mathrm{T} 2=$ Eichhornia crassipes; $\mathrm{T} 3=$ Chromolaena odorata $; \mathrm{T} 4=$ Euphorbia graminea; $\mathrm{T} 5=$ Alternanthera brasiliana; $\mathrm{T} 6=$ Chicken manure; T7 = N.P.K (15:15:15); T8 = Control (no treatment); $\mathrm{T}=$ treatment

\begin{tabular}{lcccccc}
\multicolumn{6}{c}{ Table 4: Mean growth parameters for Corchorus olitorius at seventh week } \\
\hline & $\begin{array}{c}\text { Plant } \\
\text { T }\end{array}$ & $\begin{array}{c}\text { Leaf } \\
\text { Height }(\mathrm{cm})\end{array}$ & $\begin{array}{c}\text { No. of } \\
\text { leaves }\end{array}$ & Girth $(\mathrm{cm})$ & $\begin{array}{c}\text { Biomass } \\
(\text { Fresh weight })\end{array}$ & $\begin{array}{c}\text { Days to first } \\
\text { flowering }\end{array}$ \\
\hline T1 & $71.80 \pm 3.79^{\mathrm{b}}$ & $55.15 \pm 4.10^{\mathrm{bc}}$ & $20.83 \pm 3.69^{\mathrm{b}}$ & $1.55 \pm 0.17^{\mathrm{b}}$ & $50.13 \pm 5.40^{\mathrm{bc}}$ & $66.25 \pm 1.03^{\mathrm{a}}$ \\
T2 & $69.73 \pm 3.33^{\mathrm{b}}$ & $57.68 \pm 1.53^{\mathrm{bc}}$ & $16.48 \pm 1.63^{\mathrm{ab}}$ & $1.60 \pm 0.12^{\mathrm{b}}$ & $45.60 \pm 3.00^{\mathrm{bc}}$ & $64.00 \pm 2.04^{\mathrm{a}}$ \\
T3 & $63.43 \pm 3.85^{\mathrm{ab}}$ & $49.60 \pm 4.76^{\mathrm{bc}}$ & $17.25 \pm 0.75^{\mathrm{ab}}$ & $1.33 \pm 0.06^{\mathrm{ab}}$ & $43.63 \pm 4.42^{\mathrm{bc}}$ & $68.00 \pm 0.00^{\mathrm{a}}$ \\
T4 & $62.38 \pm 2.21^{\mathrm{ab}}$ & $46.08 \pm 4.18^{\mathrm{b}}$ & $17.15 \pm 1.49^{\mathrm{ab}}$ & $1.33 \pm 0.06^{\mathrm{ab}}$ & $40.85 \pm 4.41^{\mathrm{b}}$ & $69.25 \pm 0.48^{\mathrm{a}}$ \\
T5 & $67.40 \pm 4.19^{\mathrm{b}}$ & $64.90 \pm 5.96^{\mathrm{c}}$ & $21.00 \pm 0.83^{\mathrm{b}}$ & $1.60 \pm 0.04^{\mathrm{b}}$ & $56.38 \pm 4.59^{\mathrm{c}}$ & $64.75 \pm 2.17^{\mathrm{a}}$ \\
T6 & $69.25 \pm 6.18^{\mathrm{b}}$ & $56.93 \pm 8.46 \mathrm{~b}^{\mathrm{c}}$ & $20.90 \pm 2.01^{\mathrm{b}}$ & $1.55 \pm 0.12^{\mathrm{b}}$ & $51.45 \pm 7.25^{\mathrm{bc}}$ & $66.25 \pm 1.75^{\mathrm{a}}$ \\
T7 & $66.78 \pm 2.43^{\mathrm{b}}$ & $54.55 \pm 3.53^{\mathrm{bc}}$ & $21.48 \pm 2.41^{\mathrm{b}}$ & $1.38 \pm 0.09^{\mathrm{ab}}$ & $48.35 \pm 2.08^{\mathrm{bc}}$ & $65.25 \pm 1.55^{\mathrm{a}}$ \\
T8 & $52.53 \pm 4.64^{\mathrm{a}}$ & $31.78 \pm 3.25^{\mathrm{a}}$ & $11.98 \pm 0.58^{\mathrm{a}}$ & $1.10 \pm 0.04^{\mathrm{a}}$ & $23.55 \pm 2.83^{\mathrm{a}}$ & $65.75 \pm 2.50^{\mathrm{a}}$ \\
\hline
\end{tabular}

Mean values of the same parameter along the same column having the same superscript are not significantly different (DMRT P=0.05); $\mathrm{T} 1=$ Tithonia diversifolia $; \mathrm{T} 2=$ Eichhornia crassipes; $\mathrm{T} 3=$ Chromolaena odorata $; \mathrm{T} 4=$ Euphorbia graminea $; \mathrm{T} 5=$ Alternanthera brasiliana $;$ T6= Chicken manure; T7= N.P.K 15:15:15; T8 = Control (no treatment); $\mathrm{T}=$ treatment
Effect of treatments on growth parameters of $C$. Olitorius at week six: In the sixth week, T6 recorded $(\mathrm{P} \geq 0.05)$ than all other treatments. $\mathrm{T} 8$ recorded the lowest values in all parameters. T8 was significantly lower $(\mathrm{P} \leq 0.05)$ than all treatment in stem girth, but as however not significantly lower $(\mathrm{P} \leq 0.05)$ than $\mathrm{T} 3$

Effect of treatments on growth parameters of $C$. olitorius at week seven: Six growth parameters were measured in the seventh week (Table 5). T1 (Tithonia ersifolia) had the highest mean plant height $(71.80$ mean LA, fresh biomass and stem girth (shari position with $\mathrm{T} 2$ in stem girth). There was no significance difference $(\mathrm{P} \leq 0.05)$ in number of days to first flowering. T8 (control) had the lowest mean values in all parameters except days to flowering which occurred in T2. However, T8 was significantly lower $(\mathrm{P} \leq 0.05)$ than all treatments in LA and fresh biomass. T8 was also significantly lower $(\mathrm{P} \leq 0.05)$ than all parameters except $\mathrm{T} 3$ and $\mathrm{T} 4$ in mean plant height, T2, T3 and T4 in LN and T3, T4 and T7 (N.P.K) in stem girth (Table 5). 
In the tropics, soil fertility is generally low (Hartemink, 2003; Zingore et al., 2003) and in tropical Africa, soil fertility issues have become of mounting interest due to the growing need to achieve food security for a rapidly expanding population (Hossner and Anthony, 1999). Report has shown that in Nigerian, soils are inherently infertile, leading to a decline in crop yields (Obi and Ebo, 1995). As expected in the present study, Colitorius grown in the control soil that received no treatment showed very poor growth compared to all treated soils, especially in the periods prior to crop harvest. Hence, this study further confirms the need for adequate treatment to rejuvenate soils for optimum productivity of crops in tropical cropping systems (Fayemi, 1999). It was also evident that application of organic and inorganic amendments increased tested growth parameters in $C$ olitorius.

The use of inorganic or chemical fertilizer has been campaigned as the quickest and easiest way of increasing yield per unit area (Law-Ogbomo and Remison 2007). In this study, however, Corchorous olitorius grown on soil treated with NPK showed lower performance in most tested parameters compared with soils treated with Poultry manure, $T$. diversifolia and E. crassipes throughout the study and Alternanthera brasiliana in the later weeks of study, except in number of leaves, where NPK treated soils showed highest mean values (but not significantly) compared with most of the treatments in only in two of the seven weeks of study. This result agrees with the findings of Law-Ogbomo and Osaigbovo (2016) who reported that highest herbage and dry matter yields of $C$ olitorius were obtained with organic manure compared to NPK. Moreover, report has shown that the use of inorganic fertilizer could result in soil acidity, which consequently may result in reduction in growth rate of plants (Suresh et al., 2004) and long term deterioration of soil physical properties especially the soil structure, owing to the depletion of organic matter (Gordon et al., 1993).

The use of poultry manure as organic amendments to improve soil fertility with resultant increase in crop yield has been reported by some researchers (Adenawoola and Adejoro, 2005; Senjobi et al., 2013; Emuh, 2013).

In this study, soil treated with poultry manure showed best performance compared to all other soil treatments especially in the first five weeks. However, it did not significantly $(\mathrm{p} \leq 0.05)$ improve growth of C. olitorious compared to treatment with green leaf manure prepared from $T$. diversifolia and Eichhornia crassipes for most part of the study and Alternanthera brasiliana at harvest. Earlier report (McNeill et al., 1980) and observations drawn from this study has shown that although chicken manure has great soil fertility potential, the problem involved in processing it prior to utilization is cumbersome. In addition, chicken manure requires time where it has to be dried before it can be effectively utilized and has been reported to inhibit germination and growth of plants if used fresh and unprocessed (Wong et al., 1983).

Among the invasive plants utilized as green leaf manure this study, results obtained revealed that $T$. diversifolia showed the best performance especially in the first five weeks of study, although not significantly different ( $\mathrm{p} \geq 0.05$ ) from other green leaf treatments in most parameters. This was closely followed by Eichhornia crassipes. Reports has shown that soil treated with green manure prepared from $T$. diversifolia has been successfully utilized to improved crop yield in maize, beans and vegetables in Kenya (Jama et al., 2000), yams in Nigeria (Adeniyan et al., 2008) and rice (Nziguheba et al., 2002). Reports has also revealed that $E$. crassipes has been used as organic manure for growing tomato (Kayum et al., 2008), Rice (Amitava et al., 2008) Brassica juncea (Nuka and Dubey, 2011) and Maize (Chukwuka and Omotayo, 2008).

Furthermore, Alternanthera brasiliana treated soils, although showed the least performance compared to all treatments including the control in the first four weeks, had highest mean leaf area and stem girth in the last two weeks prior to harvest and highest fresh biomass at harvest. Corchorus olitorius is a leafy vegetable (Asomani-Boateng et al., 1996). Therefore increased leaf parameter is an important economic criterion in this vegetable, especially if it occurs prior to flowering and seed set (as is the case in $A$. brasiliana) which is regarded as the best time for harvest. Thus, based on the result obtained from this study, it can be concluded that A. brasiliana also showed great potential as green leaf manure. Soils treated with Chromoleana odorata, and Euphorbia graminea showed least performance in plant parameters, although these were significantly higher $(\mathrm{p} \geq 0.005)$ than the control in later weeks. This finding agrees with the report by Paraye (2012) who on utilizing Chromolaena odorata as green manure on rice reported little effect on rice yield. In addition, soils treated with green leaves of $A$. brasiliana, $C$. odorata and E. gramineas showed delay in improving soil 
fertility in the first four to five weeks of study as reflected by poor crop performance during this period. Late improvement from these compared to the other treatments may have resulted from slow and gradual nutrient release at the early stages of their application. This agrees with some reports that organic manure increases the nutrient status of the soil through slow and gradual release of nutrients to the soil (Egherevba and Ogbe, 2002; Ibeawuchi et al., 2006; Shukla et al., 2013).

Conclusion: Data obtained from the present study revealed that green leaf of $T$. diversifolia, E. crassipes and $A$. brasiliana showed great potential as soil amendments comparable to Poultry manure and were better than NPK at harvest. However, Chromolaena odorata and Euphobia graminea were not good alternatives to either NPK or Poultry manure. This is probably a first report on the use of Alternanthera brasiliana and Euphorbia graminea as green leaf manure.

\section{REFERENCES}

Adenawoola, AR; Adejoro, SA (2005). Residual effects of poultry manure and NPK fertilizer residues on soil nutrient and performance of Jute (Corchorus olitorius L.). Nig. J. Soil Sci.15: 133 135.

Adeniyan, OB; Ojeniyi, SO; Akinola, MO (2008). Effect of weed mulch on soil properties, growth tuber yield and nutrient content of Yam (Dioscorea rotundata poir). J. Agric. Sci. 2: 70- 74.

Amitava, R; Sarkar, NC; Debashish, S (2008). Influence of organic manures on productivity of two varieties of rice, J. Cent. Eur. Agric., 9(4): 629634.

Asomani- Boateng, R; Haight, M; Furedy, C (1996). Community composting in West Africa. Bio-cycle. 37 (1): 70-71.

Chandrasekaran, S; Swamy, PS (2009). Prosopis juliflora invasion into the semi-arid ecosystems in selected villages of Ramnad district in Tamilnadu. Thesis submitted to the Department of Plant Sciences, Madurai Kamaraj University, India, 14 pp

Chukwuka, KS; Omotayo, EO (2008). Effects of Tithonia green manure and water hyacinth compost application on nutrient depleted soil in SouthWestern Nigeria. International Journal of Soil Science 3(2): 69-74.
Coblentz, BE (2002). Principle of wildlife conservation, Department of fisheries and wildlife, Oregon state university.

Dania, SO; Akpansibi P; Eghagara, OO (2014).Comparative effects of different sources on the growth and Nutrient content of Moringa (Moringa oleifera) seedlings in greenhouse trial. Advances in Agriculture, Article ID 726313, 6 pages

Darmody, RG; Foss, JE; McIntosh, M; Wolf, DC (1983). Municipal sewage sludge compostamended soil: Some spatio temporal treatment effects. J. Environ. Qual., 12: 231-236.

Egherevba, RKA; Ogbe, FM (2002). The effects of different levels of organic and mineral fertilizers on the yield performance of two Amaranths (A. cruentus) cultivars. Plt Sci. 3: 62-72.

Emuh, FN (2013). Growth and yield performance of Corchorus olitorious L. influenced by levels of poultry manure in Niger-Delta, Nigeria. Afr. J. Biotechnol. 12(19): 2575-2580

Fayemi, PO (1999). Nigerian Vegetables. Heinemann Educational Books, Nig. Plc. Ibadan.

Gibbs, HK; Ruesch, AS; Achard, F; Clayton, MK; Holmgren, P; Ramankutty, N; Foley, J.A. (2010).Tropical forests were the primary sources of new agricultural land in the 1980s and 1990s. PNAS 107: 16732-16737.

Gordon, WB; Whitney, DA. Raney, RA. (1993). Nitrogen management in furrow irrigated, ridgetilled corn. J. Production Agric. 6:213-217

Hartemink, AE (2003). Soil fertility decline in the tropics - With case studies on plantations. CAB International. Wallingford, U.K.

Hejda, M; Pysek, P; Jarosk, V (2009). Impact of invasive plants on the species richness, diversity and composition of invaded communities. J. Ecol. 97: 393-403.

Hossner, RL; .Anthony, SR (1999). Soil nutrient management for sustained food crop production in upland farming systems in the tropics. Juo Soil and Crop Sciences Department College Station Tennessee 77843 Retrieved October 202017

Ibeawuchi, II; Onweremadu, EU; Oti, NN (2006). Effects of Poultry Manure on Green 
(Amaranthuscruentus) and Waterleaf (Talinumtrinagulare) on Degraded Ultisol of Owerri Southeastern Nigeria. J. Animal and Vet. Advances 5; 53-56

Jama, B; Palm, CA; Buresh, RJ; Niang, A; Gachengo, C; Nziguheba, G; Amadalo, B (2000). Tithonia diversifoliaas a green manure for soil fertility improvement in western Kenya: A review. Agrofor. Sys. 49, 201-221.

Kayum, MA; Asaduzzaman, M; Haque, MZ (2008). Effects of Indigenous Mulches on Growth and Yield of Tomato, J. Agric. Rural. Dev., 6(1-2): 16.

Law-Ogbomo, KE; Remison, SU (2007). The response of Dioscorea rotundatato NPK fertilizer in Edo State, Nigeria. Res. J. Agric. Bio. Sci. 3: 917-923.

Law-Ogbomo, KE; Osaigbovo, AU (2016). Growth and yield of ewedu (Corchorus olitorius) as influenced by food waste compost and inorganic fertilizer in a humid ultisol of southwestern Nigeria. Nig. J. Agric. Food Environ. 12(1): 80-84

McNeill, SG; Ross, IJ; White, VM; Taraba, JL (1980). Drying characteristics of poultry excreta in a deepbed continuous drying system livestock waste: A renewable resource. Proceedings of the 4th International Conference on Livestock Wastes, (LW 80$)$, ASAE, Joseph, MI.

Nuka, L; Dubey, V (2011).Response of water hyacinth manure on growth attributes and yield in brassica juncea.J. Cent. Euro. Agric.12 (2):336-343

Nziguheba, G; Merckx, R; Palm, CA; Mutuo, P (2002). Combining Tithonia diversifolia and fertilizers for maize production in a phosphorus deficient soil in Kenya. Agrofor. Syst. 55: 165-174.

Obi, ME;Ebo,PO (1995). Effect of organic and inorganic amendments on soil physical properties and maize production in severely degraded sandy soil in Southern Nigeria. Biores. Technol. 51: 177183.

Oyetunji, OI; Ekanakaye, IJ; Osonubi, O (2003). Influence of arbuscular mycorrhizae fungus, mulch and fertilizer application on yield of-yams in an agroforestry system in South Western Nigeria. Maurik Bull 6: 75-82.
Palm. CA; Myers, RJK; Nandwa, SM (1997). Combined use of organic and inorganic nutrient sources for soil fertility maintenance and replenishment. In: R.J. Buresh et al. (eds). Replenishing Soil Fertility in Africa. SSA Special Publ . 51.193-217.

Paraye, PM (2012). Studies on green manuring of Chromolaena odorata in aromatic rice (oryza sativa) in India. PhD Thesis, University of Agricultural Science, Dhaward.

Pera, AG; Vallini, I; Sireno, ML; Bianchin, M (1983). Effect of organic matter onrhizosphere microorganisms and root development of sorghum plants in two different soils. Plant Soil, 74: 3-18.

Rahman, SA (2004). The place of organic manure in sustaining agricultural development in Nigeria. Paper presented at science technology and society national workshop in Lafia, Nasarawa state.

Rands, M; Adams, W; Bennun, L; Butchart, S; Clements, A; Coomes, D; Entwistle, A; Hodge, I; Kapos, V; Scharlemann, J; Sutherland, W; Vira, B (2010). Biodiversity conservation: Challenges beyond. Science 329: 1298-1303.

Senjobi, BA; And, OT; Senjobi, CT;Adepiti, AO; Adigun, MO (2013). Performance of Abelmoschuses culentus (L) Moench (OKRA) under various applications of pesticides and fertilizers in an OxicPaleustalf. Int. J. Plant Soil Sci. 2(1):24-40.

Shukla, S; Hanlon, EA; Jaber, FH; Stoffella, PJ; Obreza, TA; Ozores-Hampton, M;(2013). Groundwater Nitrogen: Behavior in Flatwoods and Gravel Soils Using Organic Amendments for Vegetable Production. University of Florida Institute of Food and Agricultural Sciences. Retrieve October 42017 from http://edis.ifas.ufl.edu/ae400

Steffen, R (1979).The value of composted organic matter in building soil fertility. Comp. Land Utilizat., 20: 34-37

Suresh, DS; Goyal, KK; Mundra, M (2004). Microbial biomass carbon and microbial activities of soils receiving chemical fertilizers and organic amendments. Arch. Agron. Soil Sci., 50: 641-647.

Tully, K; Sullivan, C; Weil, R; Sanchez, P(2015).The State of Soil Degradation in Sub-Saharan Africa: 
Baselines, Trajectories, and Solutions. Wong, MH; Cheung, YH; Cheung, CL (1983). The Sustainability 7: 6523-6552 effects of ammonia and ethylene oxidein animal

Vilá, M; Espinar, J L; Hejda, M; Hulme, PE; Jarošík, manure and sludge on the seed germination and root elongation of Brassica para-chinensis (flowering V; Maron, JL; Pergl, J; Schaffner, U; Sun, Y; Pyšek, P (2011). "Ecological Impacts of Invasive Alien Plants: A Meta-Analysis of Their Effects on Species, Communities and Ecosystems," Ecology Letters, 14 (7): 702-708.

Willer, H; Yuseffi-Menzler, M; Sorensen, N (2008) The world of organic agriculture: Statistics and emerging trends 2008 (International Federation of Organic Agriculture Movements (IFOAM) Germany) Retrieved Jan 13, 2014 from $<$ http://orgprints.org/13123/4/world-of-organicagriculture-2008.pdf $>$.

Chinese cabbage). Environmental Pollution Series A. Ecol. Biol. 30: 109-123.

Xu, H; Qiang, S; Genovesi, P; Ding, H; Wu, J; Meng, L; Han, Z; Miao, J; Hu, B; Guo, J;Sun, H;Huang, C; Lei, J; Le, Z; Zhang, X; He, S; Wu, Y; Zheng, Z; Chen, L; Jarosk, V; and Pysek, P(2012). An inventory of invasive alien species in China. NeoBiota 15: 1-26.

Zingore, S; Mafongoya, P; Nyamugafata, P; Giller, KE (2003). Nitrogen mineralization and maize yields following application of tree prunings to a sandy soil in Zimbabwe. Agroforesty Systems 57: $199-211$. 